\title{
Education: Quality VS Quantity. A Challenge to Link and Match Policy
}

\author{
Emi Zuiaifah
}

The issue on Indonesia's Education has mostly been looked upon from quantitative point of view. Many report on human resources development, especially through the educaional agents, relied their analysis on educational development quanlitatively. Later in this writing, I refer this orientation as quantity ariented education. As an agent of people development, quantity orientation in education is facing a critical point regarding its ability to prepare human resources for a new era of international compelition.

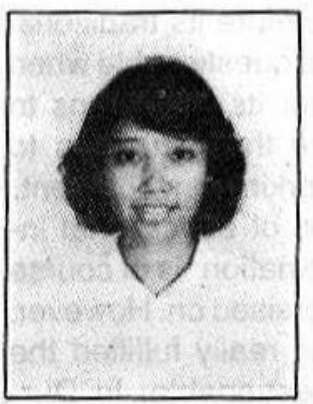

Dra. Eml Zulaifah was bom in rogyakarta on June 3 . 1968. She is presently a facuity member at The School of Psychology. Islamic University of Indonesia. Before involving har. solf into an academic world, Erri was a journalist at REPUBLIKA Daily. Besides teaching Industrial and Organizational Psychology, she is interested in doing research on work othics and behavior. This paper was written after she attended series lectures on Issues in Indonesian Development at indonesia-Australia Language Foundation, 1995 .

\section{Introduction}

TC he presence of quantitative education orientation is an understandable fact. This is developed based on the priority of Repelita I in this field, which is to widely spread the accessibility of education (from its lowest level), as a response to the peoples need. Despite the large area and the huge number of Indonesia's population, equai access into education was not yet achieved in the beginning of the development. Equality, in terms of entrance to education is really something to be provided in order to improve the level of human capital (Tambunan, 1994). The policy, run through INPRES programs was aimed at achieving compulsory education for the primary school aged population and at increasing 
the fiteracy level of people all over the country. It does show a great result of improvement: the literacy level increases by over $90 \%$ by the end of REPELITA IV. Meanwhile the number of primary schools has vastly increased from 65.910 (in 1973-4) to 146.558 (in 1990-1) and the number of pupils attended school has doubled from 13.1 million to 26.5 million.

As years pass by, however, challenge in education has transformed itself into a different form. It has been shifting from quantity orientation to the more quality oriented. The underlying condition is that as the country is gearing itself to industrialization, the need for qualified human resources to support its process appears to the front.

This orientation seems much more relevant when it is put into the context of international competition. After the signing of General Agreement on Tarifts and Trades (GATT) the barriers to expand business and industries (in its various forms of products and services) gradually diminish. A more open interaction, cooperation also competition between nations is widely available.

This does not exclude the competition among the human resources. International, skilled, more advanced and well-prepared human resources are now freely invited to actualize themselves in any part of the world. To the more developed countries, a more open world is of a great advantage: This might mean (in terms of people) a wider opportunity to make use of their capabilities > However, to the less developed nations, such as Indonesia, it creates an imbalance interaction, with more disadvantages for its part and a large and heavy assignment on knowledge, technology and skill transfer in order to be able to conform to the changes appropriately.
Countries in East and South East Asia are said to be the major players in the global economy (Fichman, in Luthans, 1992). Countries such as Singapore has run halfway for its year 2000 vision. Malaysia, too, has already formulated its 2020 vision as a response to the great demand of international competition. One agenda derived from their vision is on preparing human resources, directed to be more adaptable with international changes and demand. At universities, for example, students who take arts as their majors are exposed to subjects on human resources development, as well as its micro aspect, management. indonesia too, seem to try to formulate new vision for its development. This has resulted in the idea of - to name some-- IPTEK and MTAK, Link and Match, and emphasize its concentration on Human Fesources development.

Apparently, within the context of competition and major environment changes, there need to be some creative approaches to develop human resources. Education institution will play the most basic role to perform this task. Therefore its traditional "quantity orientation" is questionable when related to the ability for its institutions to professionally prepare their students to enter a real life and working environment.

The wide provision of educational institution throughout the nation is of course an achievernent to be praised on. However. whether this effort has really fulfilled the country's need is questionable. In DurKheim's term, improving education quantitatively (i.e., increase the number of schools, teachers and people enrollment) is a necessary factor to be provided if one country wants to proceed in its development. There is however another factor called as "a sufficient "factor" which is equally important in the process. Thus, beyond the necessary factor (the availabil- 
ity of educational Institution and equal access for all people), the sufficient factor that mainly deals with the quality of the education need to be considered.

This "quality education" orientation will actually refer to the management of this specific field as it has to continuously follow the rapid growth of economy. Within this regard, it is apparent that quality oriented education is tightly related to the "Link and Match Policy" announced by the government recently. This policy is expected to answer the need for qualified supply of human resources from education to the industries.

The same concern was raised by Pangestu and Gardiner (1993). They noted the littie priority that has been given to the quality of the education, instead of the improvement of the accessibility of schools. Given the fact that population growth is getting more stabilized, then it is important for the quantity oriented education to be reviewed and modified. Other than that, it is suggested to put attention more on quality education, due to the increase of small scale and middle scale industries requiring skilled employee and labor.

After raising this concern on the need to shift the orientation to quality education, this writing will discuss and show arguments on what quantity education has resulted in, how the field has been managed. and to identify some shortcomings that call for improvements.

\section{Mismatch Between Employment and Education}

Aside of the long trial and error on the education area (including the trial and error in curriculum changes), the product of education - graduate from all level- in Indonesia has shown an immense mismatch from its demand (the industries/ employment). This is in fact what quantity education has led into. The link and match policy, as mentioned before, is directed as counter policy to the mismatch betwoen the two areas.

There are some indicators that show the existing mismatch and the reason it takes place. In fact, education system which has been developed in Indonesia is subject to many criticism. From the management point of view, there has been an ongoing mismanagement in education. Some critics (one of them is Muchtar Buchori) bitterly said that education is an area targeted to develop human resources. Ironically, it has been poorly managed. As a result, the quality of the products, which is the graduates from all level cannot be expected to suit the need of the country.

Regarding its human resources management, schools (the representative institution of education) are very low in quality. Many primary and secondary school teachers suffer from the low incentive they receive periodically, in spite of the number of students they have to supervise. It even can be said that the government has come to a discriminatory action regarding compensation for educational employee. Within this condition, $t$ is difficult to expect high dedication and morale among educators.

Teaching, historically, held a very prestigious career choice. In the colonial times, people refer to teacher as "Mantri Guru" similar to what is now still widely used in Japan, i.e., "Sensei". The decline of teacher's status perhaps partly due to the low incentive that teachers do receive. People then think that teaching is not a kind of employment that invites reasonably good income and therefore avoid it. Other than that, many teachers are found involved in extra activities (part time works/ teaching) to add more support for their ability to survive economically. It is then ironical that 
the very basic agent for human resources improvement is left behind.

We need of course to look also into IKIP (The Teaching and Education Institute), the very institutions for supplying teachers. The more basic problems to the education development in Indonesia are actually rooted in the matter faced by IKIP. As the part that plays role in creating resources for education, i.e., teachers, IKIP does not seem to have strong foundation. If invites second class students - those who are excluded from prominent university selection. Even, it has become a public secret that IKIP academics will not recommend their children to attend the same institute.

It was unfortunately developed for meeting the target (number of teachers needed for the country). Again, this is a quantity based orientation. As a result, IKIP does not hold strong vision to proceed, other than its mission to respond to the need for educators. in general, Indonesia has not yet developed an integrative approach to its education. IKIP is an example on how this part is run awkwardly. Lately, people are shocked by the fact that the government has planned to convert it to university mainly because the quantity of graduated teachers exceeds the demand for teaching resources. This has become a big issue in education within the recent years.

Other than the low incentive and the weak supplying institution, in terms of facilities and curriculum, education in Indonesia is questionable. Pangestu and Gardiner address problem as still existing irrelevant curriculum. This in turn, leads also to the low quality of the product (graduated students). Although the demands of vocational school graduate are immense, the capability of the system to produce weft qualified ones is low. Besides, many students of vocational school are over- whelmed by subjects that are not relevant to their study. These have been done so simply because the government has recommended them to include subjects (such as social sciences, arts, physics, chemistry and biology) similar to those in general schools. It seems that there is a tendency toward uniformity, including education, in Indonesia.

On tertiary level (University, Academy, Higher Education and Institute) the mismatch show a far worse impact. Ananta, a demographer from Indonesia University. questioned whether we do need to encourage students to go to Universitites, although many fresh $\mathrm{S} 1$ graduates remain unemployed

Further he noted that there is a spurious assumption among the people about the importance of education. People are actually not well planned in pursuing their education. There is a misdirection between what they want to do in the future and what they pursue to study. While many social sciences and humanity graduates score high on unemployment level, 70 out of 100 university students attend to study these fields. The data shown by Gardiner also indicate the mismatch: Well-demanded areas are actually metallurgy, information system and technology, electronics, as wel as microbiology, whereas students most likely enter other areas in universities.

It is clear then that there is a striking absence in communication between the industries and business community and the education provider. Unlike East Asian countries that started to shift their education system to be more responsive to labor market demands, Indonesia has just staried so raise this concern. Based on both societal attitudes and government policy, education is stitl seen as an end in itself not as means to an end (Pangestu and Gardiner, 1993). 
Thus, of the link and match policy is going to be applied there need to be a radical changes in our education system. it involves not only on micro level of education management (to be quality oriented) but also on the very basic viewpoint of the people.

\section{Link and Match And Quality Oriented Education}

Despite the difficulties, considering the major demand of graduates, quality oriented education appears to be inevitable. Producing a vast number of graduates will only mean little for the development when they do not suit the need of the country. Based on the link and match policy, which tries to connect the need from the employ. ment sector to education, quality oriented education as a "sufficient" factor should be developed.

Within quality education skill and talent development is emphasized. Students who are not interested in sciences or general knowledge are free to choose area that suits best to their interest. It shou'd be kept in mind that education is not merely broaden out students' knowledge. It is also a media to develop talent, interest and skill.

Besides facilitating their development, intense counselling is needed for the students to choose their career path. Such programs are expected to eliminate the confusion on whether to choose academic or entation or to directly involve themselves into professional work through skill development.

Models on how link and match has been applied are usually available in the more developed countries (including the East Asians). In Australia National Universities, for example, the Graduate Business Administration courses are directed to suit Asia-Pacific orientation. This is done be- cause the area has become an increassing major power of economic growth.

In the lower lever, students are not necessarily oriented to go to universities. They are confidence to choose any professional field which match their own capabilities. Therefore, classes such as craft, social work practices, information technology, home economics, etc. are seriously run in secondary schools.

Through the link and match policy, various programs can be suggested. Industries are expected to channel themselves to education institutions. Workshops among the two fields will be of great help. It will be very valuable also for the students to learn what working environment and challenges are tike. Besides using workshops as the media, this can carried also by providing opportunity for firlsd practices. This way, they have better thoughts of what they have to prepare to enter employment and also wider ideas on how to improve working condition.

At university and academy level, the orientation to create $S 1$ or $D 3$ graduate with extra qualification is inevitable. Some private universities have shown themselves to try to respond to this demand. Learning foreign languages, for example is compulsory with extra hours added to the national curriculum. Other than English, languages such as Japanese, Mandarin are also offered. Providing means to leam foreign languages is hoped to allow the students to interact internationally and therefore respond to the demand of global trade more appropriately.

Extra activities, such as seminars on human resources (especially for social and arts students) and exchange sessions that invite practitioners to share their experiences are routinely held besides academic seminars. Exposures to such information are expected to shilt students from mainly 
theory oriented to practices and experience oriented, as well as providirg them to learn on how they shall equip themselves for various employmert.

In order to run a serious Link and Match programs, schools are expected to fulfill its sufficient factor: quality oriented. in selecting studerits, for instarice, numbers should be put secondary. The main priority is to provide them with sulficient education, not to recruit as many studerits as the space will allow. Having a large number of studerits is possible only wherı the institution provide a balance resources -people, finarıce, techriology e.t.c.- to rurı a well and comprehensive education process. This is ,unfortunately, what seems to be lacking in mary institutions in this country.

\section{Conclusions}

Respondirıg to the international change should be carried out from its basic level: human resources developmerit through education. The traditional orieritation that stress the importarice of providirig as many educational institutions as possible to serve a wider access is becoming less relevant. A new challenge for education is to create a quality orierted system. Within this system the erihancement of talerit and skifl as well as the preparation to enter employmert is given more space. Quality oriented education provide answers for the lirk and match policy to proceed more evenly and for education institutions to bring about wellequipped graduates.

\section{Peferences}

Ananta, A. 1995. Pemanfaatarı SDM, Ada Kekeliruarı Besar. Kompas, 6 November, P.T. Gramedia, Jakarta.

Luthans, F. 1992. Orgarizational Behavior, Sixth Edition. Singapore. Mc.Graw Hill Book. Co.

Pangestu.M. and Gardirier, O.M. 1993. Human Resources Development and Management irı Irıdonesia, Indonesia Quarterfy, vol XXXI, No. 4, 1993 , CSIS, Jakarta.

Tambunan,T. 1994. Poverty Arid Humarı Resources Development in indonesia: A brief Survey. Indonesia Quarterly. vol. XXIII, No. 2, CSIS, Jakarta. 